\title{
Neonatal infections in Saudi Arabia: association with C-reactive protein, $C R P-286(C>T>A)$ gene polymorphism and IgG antibodies
}

\author{
Amre Nasr ${ }^{1,2,3}$, Gamal Allam ${ }^{1,4}$, Ali Al-Zahrani ${ }^{5,6}$ and Adnan Alsulaimani ${ }^{5^{*}}$
}

\begin{abstract}
Background: C-reactive protein (CRP) is a nonspecific, acute-phase protein that rises in response to infectious and non-infectious inflammatory processes. Infections are the single largest cause of neonatal deaths globally.

The primary aim of this study is to examine the association between CRP gene polymorphism and serum levels of CRP in correlation with early onset sepsis (EOS) infection in newborns living in Taif city, Saudi Arabia. The second aim is to examine the relationship between specific $\lg G / \lg$ subclasses and early onset sepsis (EOS) infection among these newborns.
\end{abstract}

Methods: Staphylococcus aureus (S. aureus) is one of the most common organisms related to sepsis infection in the newborn at King Abdel Aziz Specialist Hospital (KAASH). This study was conducted in Taif city, at KAASH's neonatal intensive care unit between March and August 2012. Neonates were consecutively enrolled onto the study having met our inclusion criteria (as per our research protocol).

The CRP concentration level was analysed using NycoCard ${ }^{\circledR}$ CRP Single Test. CRP -286 (C>T>A) A polymorphisms were analyzed using Pyrosequencing technology for CRP genotyping. IgG subclasses were analysed in the study population using ELISA.

Result: Logistic regression analyses showed that the AA and AC genotypes were negatively associated amongst EOS neonates compared to suspected neonates. The frequency of CC and CT were significantly associated with the EOS neonates compared to the suspected group. The levels of specific lgG1, lgG2 and lgG3 antibodies were significantly lower amongst EOS compared to the suspected group.

Conclusions: Taken together, the CRP-286 (C>T>A) A genotype polymorphism and specific lgG antibodies isotype levels can contribute to a reduced risk of EOS. Furthermore, CRP has a potential use in detecting EOS in neonates, which may mean earlier detection and management of EOS and subsequently better clinical outcome.

Keywords: CRP, CRP gene Polymorphism, IgG subclasses, Early onset sepsis (EOS), Saudi Arabia

\section{Background}

Sepsis is a systemic response to infection with bacteria, fungi or protozoa. If not recognised and treated early, the progression from sepsis to severe sepsis, septic shock, and multiple organ dysfunction syndrome is inevitable [1]. Neonatal early onset sepsis (EOS) is one of the major causes of morbidity and mortality among newborn infants occurring in $1 \%$ of term and up to $20 \%$ of very-

\footnotetext{
* Correspondence: adnamn@gmail.com

${ }^{5}$ Department of Pediatrics, College of Medicine, Taif University, Taif, Saudi Arabia

Full list of author information is available at the end of the article
}

low-birth-weight (VLBW) infants [2,3]. The mortality rate varies from $3 \%$ to $50 \%$ in early-onset sepsis, and up to $40 \%$ in late-onset sepsis [3]. There is no single definition of EOS in the newborn; various definitions exist, each with subtle differences. EOS refers to an infection of the blood stream proven by culture. EOS is usually acquired vertically from the mother and manifests in the first 24 hours to 7 days after birth [4,5], and late onset disease for infections after 7 days. Scandinavian investigators have used this scheme because infection within the first 24 hours has a higher mortality rate.

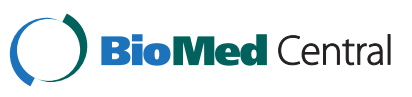


Newborn infants often suffer from bacterial infections without presenting typical symptoms such as fever. There is an increased risk of sepsis in neonates, and in particular preterm infants, due to the incomplete maturity of their immune system. Reliable methods for detecting and monitoring sepsis in the newborns would therefore be beneficial in terms of treatment and management. In older children and adults, serum/plasma levels of C-reactive protein (CRP), IgG and IgG subclass have proved useful indicators of infection and inflammation [6].

CRP is an acute-phase protein produced by the liver as part of the body's inflammatory response to bacterial infection and tissue injury. CRP is produced during fetal development, preceding the production of $\operatorname{IgG}[7,8]$. The level of CRP is known to rise in both bacterial and fungal infections in children beyond the neonatal age, but remains low or undetectable in viral infections $[9,10]$. CRP alone can be a good indicator of bacterial infection in preterm and term neonates even though it is sensitive in early infections but not specific [11]. Serum CRP reference ranges have been identified in neonates, but there is little information on the levels of CRP in maternal blood compared with those found in cord blood, showing that there is no appreciable transfer of CRP across the placenta [12]. The influence of genetic variation on the levels of circulating CRP is estimated to be $40-60 \%$ [13], and a functional polymorphism in the promoter region of the CRP gene (-286 C>T>A) (rs3091244) has been strongly associated with the circulating concentrations of CRP [14]. Previous studies of the functional $-286 \mathrm{C}>\mathrm{T}>\mathrm{A}$ CRP polymorphism have revealed that the A allele is more common in the African American than in the Caucasian population, and this difference in genotypes is associated with higher CRP levels in the former population [15]. This suggests that CRP could have been selected for in the African ancestors, as a beneficial factor for survival from infectious diseases.

IgG antibodies are monomeric, found in all body fluids, and are the dominating isotype in humoral immune responses, constituting $75 \%$ to $80 \%$ of all antibodies in the serum. Human IgG is divided into four subclasses, IgG1- IgG4, where IgG1 is the most common (66\%), followed by IgG2 (24\%), IgG3 (7\%) and IgG4 (3\%) [16]. IgG1 and IgG3 antibodies are predominantly produced in response to protein antigens [17], but chronic stimulation may result in an increased proportion of IgG4 [18]. In contrast, carbohydrate antigens most often induce IgG2 responses [17]. The different subclasses differ in their ability to activate complement, IgG1 and IgG3 being the most effective ones, IgG2 being a weak activator, whereas IgG4 does not activate complement. IgG2 antibodies are very important in targeting encapsulated bacteria. IgG antibodies are the only isotypes that can cross the placenta in the pregnant woman to help protect the neonate.
CRP increases rapidly during infections and/or inflammation. CRP has the ability to activate various immune cells and has the capacity to bind to certain FcyRs. Both CRP and IgG share a sequence homology that is important for FcyR binding [19]. The binding of CRP may compete and interfere with the binding of protective specific IgG antibodies. The R131 allele of FcyRIIa was shown to bind CRP with high affinity [20]. CRP can indirectly mediate activation of the complement and complement receptors, or directly through receptors for the FcyRs or even a putative CRP-specific receptor activation of immune cells.

The primary aim of this study is to examine the association between CRP gene polymorphism and serum levels of CRP in correlation with early onset sepsis (EOS) infection in newborns. The second aim of is to examine the relationship between specific IgG/IgG subclasses and early onset sepsis (EOS) infection among newborns living in Saudi Arabia.

\section{Methods \\ Study area}

This study was conducted in Taif city in the western kingdom of Saudi Arabia (KSA), at the Neonatal Intensive Care unit (NICU), King Abdel Aziz Specialist Hospital (KAASH), between March and August 2012. The KAASH is one of the largest specialized hospitals in Taif city, with a well-organized antenatal, postnatal clinics and NICU.

\section{Study design and patient enrolment}

A prospective cohort (cross-sectional) study was carried out over six months, between March and August 2012 in NICU at KAASH-Taif. All neonates chosen for this study were $40 \pm 2$ week gestation. This was specifically chosen to minimise the differences in the IgG concentration ranges.

Gram negative organisms are the predominant pathogens associated with EOS. However, according to hospital data from previous years, Staphylococcus aureus was the commonest pathogen at KAASH hospital. As such, we concentrated our efforts to investigate this particular pathogen [21].

The subjects were classified into three different groups. Group I is the control group where babies have no symptoms or signs of sepsis and a negative blood culture. Group II is the suspected group of neonates which includes any infant with signs or symptoms of sepsis, chorioamnionitis and those born to mothers who had intrapartum temperature $\geq 38.0^{\circ} \mathrm{C}$ or prolonged rupture of membrane $\geq 18$ hours. It is important to note that blood cultures for this group were negative. Once infection was confirmed by means of a positive blood culture or blood markers, the infant was put into Group III which is the early onset sepsis group. 
Babies suspected of having sepsis infection, after proven positive culture, were treated by clinicians (neonatologist) with double antibiotics (Ampicilin [22] and Gentamicin [23]) until the baby became symptom free or finished their course of antibiotic. Once babies were examined clinically and sepsis was confirmed; blood samples were taken within 12-50 hours of birth as per our research protocol.

If the suspected neonate had an initial negative culture but still continued to have symptoms/signs of sepsis; repeat cultures were offered within 72 hours. These neonates were automatically excluded from the study. As such, there were no repeat cultures taken.

Babies were clinically examined during their stay in NICU. Full blood count was routinely taken. All investigations and treatments were provided free of charge.

Neonates who were suspected of sepsis infection were enrolled onto the study after ethical clearance was obtained from the parents. Once the informed consent was gained, peripheral blood samples were taken. Blood samples were prepared for culture detection of bacterial species and blood from each source was plotted in filter paper. Newborns were weighed and those with low birth weight were assessed clinically to differentiate between intrauterine growth restriction or low birth weight using Dubowitiz scoring system. This scoring system assesses an infant for the apparent gestational age by considering both neurologic and external signs of development.

\section{Sample collection}

Before pharmacological treatment was started, $50 \mu \mathrm{l}$ of blood were collected on filter paper (Schleicher \& Schuell; $\mathrm{n}^{\circ}$ 903TM) for DNA amplification, CRP detection and measurement of immunoglobulin. Two $\mathrm{ml}$ of venous blood sample was collected in EDTA Vacutainer ${ }^{\circledR}$ tubes (Becton Dickinson, Meylan, France) for microbiology (bacterial) culture.

\section{DNA preparation}

DNA was extracted from filter paper using a modified version of the Chelex-100 method and stored at $-20^{\circ} \mathrm{C}$ $[24,25]$. In brief, $50 \mu$ l of peripheral blood was put on the filter paper and incubated overnight in $1 \mathrm{ml}$ of $0.5 \%$ Saponin in PBS at $4^{\circ} \mathrm{C}$. It was then washed for $15-30 \mathrm{mi}-$ nutes in $1 \mathrm{ml} \mathrm{PBS}$ at $4^{\circ} \mathrm{C}$. The discs or the pellets were boiled in $200 \mu \mathrm{l}$ of $5 \%$ Chelex-100 in water for $15 \mathrm{mi}$ nutes, and the DNA was collected in supernatants after centrifugation at 10,000 rpm for 3 minutes.

\section{CRP genotyping with pyrosequencing}

The CRP gene (tri-allelic SNP at position $-286, \mathrm{C}>\mathrm{T}>$ A) (rs3091244) was genotyped by pyrosequencing as mentioned in the references opposite [26-28].

\section{Measurement of CRP}

The serum concentrations of CRP were measured using the same version of NycoCard ${ }^{\circledR}$ CRP Single Test (AxisShield, Oslo, Norway), as described before by Israelsson et al., [28].

\section{Measurement of specific IgG and IgG subclasses by enzyme-linked immunosorbent assays (ELISA)}

An indirect enzyme-linked immunosorbent assay, ELISA [29] was used for the measurement of total IgG and the subclasses; IgG1, IgG2, IgG3 and IgG4, against specific bacterial antigens of $S$. aureus, as described earlier [30]. In brief, the plates were incubated overnight at $4^{\circ} \mathrm{C}$, and then blocked for 2 hours with $0.5 \%$ bovine serum albumin (BSA) diluted in carbonate buffer ( $\mathrm{pH}$ 9.6). Plasma samples diluted in incubation buffer (PBS + 0.5\% BSA), 1:1000 (IgG) and 1:400 (IgG1-4), was added in duplicate and incubated for 1 hour at $37^{\circ} \mathrm{C}$. The plates were washed four times, and bound IgG antibodies were detected with goat anti-human IgG-ALP (1:2000) (Mabtech, Nacka, Sweden). IgG subclasses were analyzed with their respective biotin conjugated mouse anti-human subclass specific monoclonal antibodies: mouse anti-human IgG1 1:1000 (M15015, Clone NL16, SkyBio, Bedfordshire, UK), mouse antihuman IgG2 1:3000 (555874, Pharmingen, Erembodegem, Belgium), mouse anti-human IgG3 1:1000 (MH 1532, Caltag laboratories, Paisley, UK) and mouse anti-human IgG4 1:2000 (B3648, Sigma, St. Louis, USA). Alkaline phosphatase (ALP) conjugated streptavidin (Mabtech) diluted 1:2000 was added to detect bound antibodies of IgG2-4, while ALP-conjugated to goat anti-mouse Ig (Dakopatts, Glostrup, Denmark; 1:1000) was used for IgG1 antibodies and the plates were developed with nitrophenyl phosphate (Sigma-Aldrich Chemie $\mathrm{GmbH}$, Steinheim, Germany). The absorbance was read at $405 \mathrm{~nm}$ using a $\operatorname{Vmax}^{\mathrm{Tm}}$ Kinetic microplate reader (Molecular devices, Menlo Park, USA).

\section{Ethical considerations}

This study has received ethical clearance from the Ethical Committee of the College of Medicine, Taif University, KSA. Informed consent was obtained from the neonates' parents, who were going to participate in the study after providing them with adequate information on the objectives and benefits of the project.

\section{Statistical analysis}

Statistical analysis was performed by SPSS version 10.0 software for Windows (SPSS ${ }^{\circledR}$, Inc, Chicago, IL, USA). In this study, antibody levels (IgG and IgG subclass) were analyzsed using Kruskal-Wallis test (non parametric) and the $P$ values were derived. With regards to the risk of EOS, $P$ values were considered significant if $<0.05$. Overall, the $95 \%$ confidence interval (CI) for odds ratio (OR) 
that do not cross 1.00 were statistically significance (see explanation below).

- $\mathrm{OR}=1$ Represents no statistical significance

- $\mathrm{OR}>1$ Represents significance associated with the EOS group

- OR $<1$ Represents significance associated with the suspected or sepsis free control

To assess the association between the CRP genotype and sepsis outcomes (dependent variable), logistic regression analysis was preformed. The CRP-TT genotype was used as a reference value in the analyses.

\section{Results}

\section{Characteristics of the study participants}

A total of 205 newborns, were consecutively enrolled in this study. The neonates were divided into three groups according to presence of risk factors of early onset sepsis (EOS); described previously in $[31,32]$. Group I; has 68 infants with no evidences of sepsis infection (37 girls, 31 boys; median of age at time of collection was 1 day with a range 1-2 days). Group II; has 68 infants suspected of sepsis infection ( 25 girls, 43 boys; median of age at time of collection was 1 day with a range of 1-2 days). Infants in this group were symptomatic with or without maternal risk factors and negative cultures, or asymptomatic with maternal risk factors and negative blood culture. Group III; has 69 infants with evidences of EOS infection
(26 girls, 43 boys; median of age at time of collection was 1 day with a range of 1-1 day). Infants enrolled in this group were symptomatic with or without maternal risk factors and positive blood culture.

Newborns with sepsis infection were followed after birth through the hospital neonatal unit and when presenting with complaints.

The median (range) for the three study groups differed statistically significantly in various clinical/laboratory parameters. Neonates diagnosed with EOS showed lower weight/gm compared to suspected newborn and sepsisfree controls [Overall $P$ value $<0.001$ ] (Table 1). The EOS group had lower temperature ${ }^{\circ} \mathrm{C}$ compared to suspected groups and sepsis-free controls [Overall $P$ value $<0.001$ ] (Table 1). Furthermore, EOS patients showed higher levels of CRP ( $\mathrm{ng} / \mathrm{ml})$, total white blood cells count (TWBCs/ $10^{3}$ cells/ $\mu \mathrm{l}$ ), neutrophils (\%), lymphocytes (\%) and monocytes (\%) compared with sepsis-free controls and the suspected group [Overall $P$ value $<0.001$ for each variable previously mentioned] (Table 1 ).

The median (range) of specific IgG/IgG subclass antibodies was statistically different between the study groups (Table 1). Kruskal-Wallis (nonparametric) test showed that the specific IgG/IgG subclass antibodies were significantly higher in the suspected group compared to sepsis-free controls and EOS [Overall $P$ value < 0.001 and $P$ value for IgG4 $=0.001$ ] (Table 1 ). The most dominant subclass amongst the specific antibodies was IgG2 followed by IgG3, IgG1 and IgG4 in the suspected

Table 1 Description of the study groups, sex, nationality, median (range) for (weight, temperature, CRP, IgG and IgG subclasses)

\begin{tabular}{|c|c|c|c|c|}
\hline Study groups variables & Sepsis- free controls $n=68$ & Suspected $n=68$ & Early onset sepsis $n=69$ & $P$ value \\
\hline Sex: girls n(\%) & $37(54.4 \%)$ & $25(36.8 \%)$ & $26(37.7 \%)$ & 0.06 \\
\hline Boys n(\%) & $31(45.6 \%)$ & $43(63.2 \%)$ & $43(62.3 \%)$ & \\
\hline Nationality: non-Saudi n(\%) & $8(11.8 \%)$ & $4(5.9 \%)$ & 7 (10.1\%) & 0.48 \\
\hline Saudi n(\%) & $60(88.2 \%)$ & $64(94.1 \%)$ & $62(89.9 \%)$ & \\
\hline \multicolumn{5}{|l|}{ Median (range) of: } \\
\hline Age/ day & $1(1-2)$ & $1(1-2)$ & $1(1-1)$ & $<0.091$ \\
\hline Weight/g & 3390 (3095-4960) & $2780(2375-3175)$ & $2030(1335-2021)$ & $<0.001$ \\
\hline Temperature $/{ }^{\circ} \mathrm{C}$ & $36.7(35.5-37.0)$ & $35.3(34.6-35.9)$ & $35.5(35.0-37.5)$ & $<0.001$ \\
\hline CRP ng/ml & $0.35(0.04-0.86)$ & $3.46(2.15-4.71)$ & $6.43(3.77-8.25)$ & $<0.001$ \\
\hline $\lg G$ & $0.70(0.25-3.70)$ & $2.05(0.25-17.90)$ & $0.57(0.24-7.90)$ & $<0.001$ \\
\hline $\lg G 1$ & $2.19(0.08-8.70)$ & $5.60(0.28-22.27)$ & $3.20(0.36-10.22)$ & $<0.001$ \\
\hline $\lg G 2$ & $0.68(0.28-1.00)$ & $8.37(0.22-25.89)$ & $1.52(1.02-2.81)$ & $<0.001$ \\
\hline $\lg G 3$ & $4.48(0.15-14.24)$ & $6.50(0.31-39.45)$ & $4.78(0.15-27.58)$ & $<0.001$ \\
\hline lgG4 & $0.28(0.13-0.96)$ & $0.34(0.10-3.24)$ & $0.39(0.08-2.28)$ & 0.001 \\
\hline TWBCs $/ 10^{3}$ cells $/ \mu \mathrm{l}$ & $10.43(6.9-12.5)$ & $14.45(12.5-17.1)$ & $21.72(17.1-19.3)$ & $<0.001$ \\
\hline Neutrophils\% & $3.24(0.4-5.2)$ & $7.17(5.2-9.1)$ & $12.25(9.3-12.5)$ & $<0.001$ \\
\hline Lymphocytes\% & $3.27(0.78-4.0)$ & $4.79(4.02-5.45)$ & $6.76(5.49-10.00)$ & $<0.001$ \\
\hline Monocytes\% & $0.49(0.09-0.71)$ & $1.51(1.18-3.10)$ & $1.5(1.18-3.10)$ & $<0.001$ \\
\hline
\end{tabular}


group. However, IgG3 followed by IgG1, IgG2 and IgG4 in EOS and sepsis free control groups.

\section{CRP genotypes, allele and allele carrier frequencies}

All subjects within the three study groups were genotyped for $-286 \mathrm{C}>\mathrm{T}>\mathrm{A} C R P$ single nucleotide polymorphism (SNP) in the CRP gene (rs3091244). Both allele and genotype frequencies were found to be in Hardy-Weinberg equilibrium $(P$ value $=0.201)$ (Table 2$)$. The overall genotypic frequencies differed statistically significantly between EOS patients compared to the suspected group $[\mathrm{OR}=1.34 ; 95 \% \mathrm{CI}=(1.07-1.67), P$ value $=0.010]$ (Table 2). Logistic regression analyses showed that the $\mathrm{AA}$ and $\mathrm{AC}$ genotypes were negatively associated amongst EOS patients compared to suspected neonates when using the TT genotype as a reference group in the analysis $[1.4 \%$ for EOS versus $22.1 \%$ for suspected group; OR 0.10; 95\% CI (0.01-1.27) and $P$ value $<0.001]$ and $[14.5 \%$ for EOS versus $44.1 \%$ for the suspected group; OR 0.05 ; 95\% CI (0.01-0.27) and $P$ value $<0.001]$ respectively (Tables 2 and 3 ). For AT genotype, there were no statistical differences between EOS patients compared to the suspected group $[11.6 \%$ for EOS patients versus $10.3 \%$ for the suspected group; OR 0.18 ; 95\% CI (0.03- 1.07) and $P$ value $=0.059]$ (Tables 2 and 3). The frequency of CC and CT were significantly associated with the EOS patients compared to the suspected group [30.4\% for EOS versus 11.8\% for the suspected group; OR 7.88; 95\% CI (2.66- 13.29) and $P$ value $<0.001]$ and [23.2\% for EOS versus $8.8 \%$ for the suspected group; OR 8.00; 95\% CI (2.46-16.04) and $P$ value $=0.001]$ respectively (Tables 2 and 3 ).
Table 3 Logistic regression analysis of CRP -286 (C $>T>A)$ genotype polymorphism in early onset sepsis compared with suspected patients

\begin{tabular}{lll}
\hline CRP genotypes & OR $(95 \% \mathrm{Cl})$ & $P$ value \\
\hline TT & 1.00 & \\
AA & $0.10(0.01-1.27)$ & $<0.001$ \\
AC & $0.05(0.01-0.27)$ & $<0.001$ \\
AT & $0.18(0.03-1.07)$ & 0.059 \\
CC & $7.88(2.66-13.29)$ & $<0.001$ \\
CT & $8.00(2.46-16.04)$ & $\mathbf{0 . 0 0 1}$ \\
Alleles frequency & & \\
C & $2.48(0.97-6.37)$ & 0.059 \\
T & 1.00 & \\
A & $0.24(0.10-0.57)$ & $\mathbf{0 . 0 0 1}$ \\
Alleles carriers frequency & & $<0.001$ \\
Non-A-allele & $0.13(0.06-0.27)$ & \\
A-allele & & \\
\hline
\end{tabular}

With regards to $C R P$ allele frequencies; there were significant differences between the study groups [Overall allelic frequency; $\mathrm{OR}=3.28 ; 95 \% \mathrm{CI}=(1.92-5.59)$, $P$ value $<0.001$ ] (Tables 2 ). The A allele being less frequent than the $\mathrm{C}$ allele amongst EOS patients $[0.14 \%$ for $\mathrm{EOS}$ versus $0.49 \%$ for suspected groups; $\mathrm{OR}=3.28$; 95\% CI $=(1.92-5.59), P$ value $<0.001]$ (Tables 2 and 3$)$.

As per Kovacs et al., 2005, findings, we adopted the same method of comparing individuals carrying the A allele against those who are non-A allele carriers [14]. The frequency of the A-allele carriers was dominant in newborns with sepsis infections compared to the suspected group [29\% for EOS patients versus $76.5 \%$ for suspected

Table 2 Description of CRP -286 (C>T>A) genotype polymorphism in the study groups

\begin{tabular}{|c|c|c|c|c|}
\hline CRP genotypes ${ }^{*}$ & Sepsis- free controls $n=68(\%)$ & Suspected $n=68(\%)$ & Early onset sepsis $n=69(\%)$ & Hardy-Weinberg equilibrium test \\
\hline TT & 10 (14.7\%) & $2(2.9 \%)$ & 13 (18.8\%) & 0.201 \\
\hline AA & $3(4.4 \%)$ & $15(22.1 \%)$ & $1(1.4 \%)$ & \\
\hline$A C$ & 19 (27.9\%) & 30 (44.1\%) & 10 (14.5\%) & \\
\hline AT & $13(19.1 \%)$ & $7(10.3 \%)$ & $8(11.6 \%)$ & \\
\hline $\mathrm{CC}$ & $18(26.5 \%)$ & $8(11.8 \%)$ & $21(30.4 \%)$ & \\
\hline $\mathrm{CT}$ & $5(7.4 \%)$ & $6(8.8 \%)$ & $16(23.2 \%)$ & \\
\hline \multicolumn{5}{|l|}{ Alleles frequency ${ }^{\ddagger}$} \\
\hline C & 0.44 & 0.38 & 0.50 & \\
\hline $\mathbf{T}$ & 0.28 & 0.13 & 0.36 & \\
\hline A & 0.27 & 0.49 & 0.14 & \\
\hline \multicolumn{5}{|l|}{ Allele carriers ${ }^{\S}$} \\
\hline Non- A- Allele & $33(48.5 \%)$ & $16(23.5 \%)$ & $49(71.0 \%)$ & \\
\hline A- Allele & 35 (51.5\%) & $52(76.5 \%)$ & $20(29.0 \%)$ & \\
\hline
\end{tabular}

${ }^{*}$ Overall genotypic frequency; Odds Ratio $[O R]=1.34 ; 95 \%$ Confidence Interval $[C l]=(1.07-1.67), P$ value $=0.010$.

\# Overall allelic frequency; $\mathrm{OR}=3.28 ; 95 \% \mathrm{Cl}=(1.92-5.59)$, $\mathrm{P}$ value $<0.001$

${ }^{\S}$ Overall allelic carriers; $\mathrm{OR}=5.11 ; 95 \% \mathrm{Cl}=(1.74-8.01), \mathrm{P}$ value $=0.003$. 
newborns; OR 0.13; 95\% CI (0.06-0.27) and $P$ value $<0.001]$ (Tables 2 and 3).

\section{Circulating CRP concentrations}

In this study, serum CRP concentration levels were analysed in the study groups to quantify the independent relationship between the risk of sepsis infection and CRP levels. The CRP levels were grouped into third of their distributions and comparisons were made with the second categorised level as a reference value.

Logistic regression analysis revealed that levels of CRP were significantly higher amongst EOS compared to the suspected group $[\mathrm{OR}=2.31 ; 95 \% \mathrm{CI}=(1.16-4.59)$, $P$ value $=0.005]($ Table 4$)$.

\section{Analysis of CRP concentrations in relation to CRP-286 allele carriers}

The distribution of CRP-286 allele carriers and CRP levels in the whole study groups were analysed. Logistic regression analysis test showed that higher levels of CRP were associated with A-allele carriers than those with non-A-allele carriers $[\mathrm{OR}=3.24 ; 95 \% \mathrm{CI}=(1.53-6.87), P$ value $=0.002]$ (Table 5). The lower level of CRP was associated with nonA-allele carriers of $C R P$-286 were seen in the study population $[\mathrm{OR}=0.38 ; 95 \% \mathrm{CI}=(0.18-0.77), P$ value $=0.007]$ (Table 5).

Patterns of specific lgG/lgG subclass antibodies in relation to relative risk of sepsis infection

Newborns with early onset sepsis infection were used as a dependent variable in the statistical analyses. The levels of anti-S. aureus antibodies of IgG/IgG subclasses were statistically different between the EOS and suspected groups.

To quantify the independent relationship between the relative risk of sepsis infection and IgG antibody titer; the antibody levels were ranked into three groups according to their distribution. Comparisons were made with the lowest concentration (first group), which was used as a reference value. Although there were higher levels of antiS. aureus IgG1, IgG2 and IgG3 antibodies in the suspected group, they were independently associated with a reduced risk of $\mathrm{EOS}$ infection $[\mathrm{OR}=0.30 ; 95 \% \mathrm{CI}=(0.12-0.76)$, $P$ value $<0.011$ ], [For medium level of $\operatorname{IgG} 2 ; \mathrm{OR}=0.44$; $95 \% \mathrm{CI}=(0.37-0.73), P$ value $=0.001$ and for higher level of $\operatorname{IgG} 2 \mathrm{OR}=0.34 ; 95 \% \mathrm{CI}=(0.20-0.49), P$ value $=0.030]$

Table 4 Logistic regression analysis of CRP levels ( $\mathrm{ng} / \mathrm{ml}$ ) in relation to the risk of early onset sepsis compared with suspected patients

\begin{tabular}{lll}
\hline CRP levels $\mathbf{n g} / \mathbf{m l}$ & OR $(\mathbf{9 5} \% \mathrm{Cl})$ & $\boldsymbol{p}$ value \\
\hline Less than $\mathbf{0 . 2 3 9}$ & $0.52(0.22-1.21)$ & 0.129 \\
Within $\mathbf{0 . 2 4 0}$ to $\mathbf{1 . 3 0 0}$ & 1.00 & \\
Higher than $\mathbf{1 . 3 0 1}$ & $2.31(1.16-4.59)$ & $\mathbf{0 . 0 0 5}$ \\
\hline
\end{tabular}

Table 5 Logistic regression analysis of CRP levels ( $\mathrm{ng} / \mathrm{ml}$ ) in relation to CRP-286 A-allele compared with non-Aallele carriers in the combined study population

\begin{tabular}{lll}
\hline CRP levels $\mathbf{n g} / \mathrm{ml}$ & OR $(\mathbf{9 5 \%} \mathrm{Cl})$ & $\boldsymbol{p}$ value \\
\hline Less than $\mathbf{0 . 2 3 9}$ & $0.38(0.18-0.77)$ & $\mathbf{0 . 0 0 7}$ \\
Within $\mathbf{0 . 2 4 0}$ to $\mathbf{1 . 3 0 0}$ & 1.00 & \\
Higher than $\mathbf{1 . 3 0 1}$ & $3.24(1.53-6.87)$ & $\mathbf{0 . 0 0 2}$ \\
\hline
\end{tabular}

$\mathrm{OR}$ represent odds ratios while $\mathrm{Cl}$ represents confidence intervals. Non-A-allele carriers were assigned 0 ; A-allele carriers were assigned 1 in the logistic regression analysis. OR above 1 represented value associated to A-allele carriers while less than 1 value represented non-A-allele carriers.

and $[\mathrm{OR}=0.32 ; 95 \% \mathrm{CI}=(0.13-0.75), P$ value $=0.009]$ respectively (Table 6). For the IgG4 antibody was found to be statistically higher in the EOS than the suspected group $[\mathrm{OR}=2.82 ; 95 \% \mathrm{CI}=(1.16-6.90), P$ value $=0.023]$ (Table 6).

Concentration of serum CRP levels in relation to relative risk of high levels of specific lgG/lgG subclass antibodies In order to see if the specific IgG/IgG subclass antibodies levels have affected the concentration of CRP, the relationship between IgG antibody subclasses and CRP were analysed. In all of the study populations, the lower concentration of IgG2 was associated with higher levels of serum CRP level $[\mathrm{OR}=0.74 ; 95 \% \mathrm{CI}=[0.35-1.06], P$ value $=0.034]$ (Table 7). No statistical differences in levels of IgG1, IgG3 and IgG4 were seen among the different CRP levels (Table 7).

\section{Discussion}

In this study, the majority of infants (66.8\%) were diagnosed with suspected or proven EOS and were admitted to the NICU. All of the study population was evaluated for sepsis during the first week of life. Only $33.7 \%$ of the newborns had a confirmed episode of EOS. Currently, there are management guidelines addressing the need for sepsis evaluation in EOS.

It is possible that a large proportion of EOS remains culture negative due to various reasons like low bacterial load, low volumes of blood taken for culture, and maternal antibiotic therapy.

This study looked at whether clinical signs such as temperature were measured for the study population. Interestingly, it was found that the EOS and suspected groups had lower temperatures compared with sepsisfree controls. To our knowledge, neonatal fever may occur when secretion of pyretic inflammatory cytokines raises the hypothalamic temperature set point, leading to heat-conservation and heat-generation by physiologic responses. However, mechanisms besides inflammatory patterns may also lead to an elevated body temperature [33-36]. Non-infectious conditions associated with neonatal fever include dehydration, breast-feeding, high birth 
Table 6 Logistic regression analysis of IgG subclasses in relation to the risk of early onset sepsis compared with suspected patients

\begin{tabular}{|c|c|c|c|}
\hline Antibody isotopes & Categorized IgG subclasses levels & OR $(95 \% \mathrm{Cl})$ & $P$ value \\
\hline \multirow[t]{3}{*}{$\lg G$} & Lower level & 1.00 & \\
\hline & Medium level & $0.69(0.29-1.62)$ & 0.394 \\
\hline & Higher level & $0.213(0.09-0.51)$ & $<0.001$ \\
\hline \multirow[t]{3}{*}{$\lg G 1$} & Lower level & 1.00 & \\
\hline & Medium level & $1.34(0.51-3.50)$ & 0.558 \\
\hline & Higher level & $0.30(0.12-0.76)$ & 0.011 \\
\hline \multirow[t]{3}{*}{$\lg G 2$} & Lower level & 1.00 & \\
\hline & Medium level & $0.44(0.37-0.73)$ & 0.001 \\
\hline & Higher level & $0.34(0.20-0.49)$ & 0.030 \\
\hline \multirow[t]{3}{*}{$\operatorname{lgG} 3$} & Lower level & 1.00 & \\
\hline & Medium level & $0.44(0.18-1.07)$ & 0.070 \\
\hline & Higher level & $0.32(0.13-0.75)$ & 0.009 \\
\hline \multirow[t]{3}{*}{$\operatorname{lgG} 4$} & Lower level & 1.00 & \\
\hline & Medium level & $2.82(1.16-6.90)$ & 0.023 \\
\hline & Higher level & $1.71(0.73-4.00)$ & 0.213 \\
\hline
\end{tabular}

weight, and caesarean section [37-39]. Excessive handling may also elevate the newborn's temperature [40,41]. Overall rates of temperatures in EOS infants were very low, making this sign a highly specific diagnostic tool in the diagnosis of bacterial infection. The vast majority of infants presenting with high temperatures suffered severe illnesses and/or had other organ systems involved. High temperatures were extremely rare in an otherwise healthy infant without any other signs of illness.

Our results suggest that babies with EOS had a significantly lower median weight $(2030 \mathrm{~g})$ compared to suspected (2780 g)/or sepsis-free controls (3390 g).

This study demonstrates an association between CRP286 ( $A$ allele) and EOS whereby carriers of the A allele are

Table 7 Logistic regression analysis of CRP levels in $\mathrm{ng} / \mathrm{ml}$ in relation to higher antibodies isotype in the combined study populations

\begin{tabular}{|c|c|c|c|}
\hline Antibody isotopes & Categorized CRP levels & OR $(95 \% \mathrm{Cl})$ & $P$ value \\
\hline \multirow[t]{3}{*}{$\lg G$} & Less than 0.239 & 1.00 & \\
\hline & Within 0.240 to 1.300 & $0.57(0.29-1.12)$ & 0.102 \\
\hline & Higher than 1.301 & $1.310(0.66-2.57)$ & 0.434 \\
\hline \multirow[t]{3}{*}{$\lg \mathrm{g} 1$} & Less than 0.239 & 1.00 & \\
\hline & Within 0.240 to 1.300 & $1.30(0.66-2.55)$ & 0.444 \\
\hline & Higher than 1.301 & $1.46\left(0.75-2.87^{\prime}\right)$ & 0.268 \\
\hline \multirow[t]{3}{*}{$\operatorname{lgG} 2$} & Less than 0.239 & 1.00 & \\
\hline & Within 0.240 to 1.300 & $0.44(0.35-3.05)$ & 0.202 \\
\hline & Higher than 1.301 & $0.74(0.35-1.06)$ & 0.034 \\
\hline \multirow[t]{3}{*}{$\operatorname{lgG3}$} & Less than 0.239 & 1.00 & \\
\hline & Within 0.240 to 1.300 & $1.23(0.63-2.40)$ & 0.552 \\
\hline & Higher than 1.301 & $1.55(0.79-3.047)$ & 0.201 \\
\hline \multirow[t]{3}{*}{$\operatorname{lgG} 4$} & Less than 0.239 & 1.00 & \\
\hline & Within 0.240 to 1.300 & $1.23(0.63-2.40)$ & 0.548 \\
\hline & Higher than 1.301 & $0.86(0.44-1.69)$ & 0.862 \\
\hline
\end{tabular}

To quantify the independent relationship between antibodies isotype (were ranked into two groups of their distributions), and CRP levels. The CRP levels were grouped into third of their distributions and comparisons were made with last categorized level (higher concentration) as reference value. OR represent odds ratios while $\mathrm{Cl}$ represents confidence intervals. Lower concentration of antibodies was assigned 0 ; higher concentration of antibodies was assigned 1 in the logistic regression analysis. OR above 1 represented value associated to higher concentration of antibodies while less than 1 value represented lower concentration of antibodies. 
less susceptible to EOS compared with the suspected group. High levels of CRP were associated with EOS compared with the suspected group. Furthermore, EOS was associated with high levels of total white blood cells (TWBC), neutrophils and lymphocytes. This finding is in agreement with previous reports by Berger et al., 1995 which showed that high levels of CRP, TWBC and lymphocytes were comparably good tests during the first three days of life, and that CRP was the best test in the early detection of neonatal septicaemia [42].

A previous study showed that CRP secretion starts within 4-6 hours after stimulation, peaking only after 36 hours [43]. Early reports described a high prevalence of elevated CRP levels in infected infants, but levels are elevated in only $35 \%$ to $65 \%$ of neonates with bacterial infection at the onset of illness [44]. Recognition that a delay of at least several hours is intrinsic to the cascade of events leading to elevation of serum CRP levels (including activation of neutrophils, elaboration of interleukin-6 (IL-6), and induction of hepatic synthesis of CRP) [45] led to appropriate criticism of this test as having insufficient sensitivity to guide therapy either by reliably diagnosing or excluding bacterial infection [45].

The results obtained in this study (combined study group) have shown higher levels of CRP associated with A-allele carriers (high producer allele) of the CRP-286 $(C>T>A)$ in symptomatic group compared to sepsis free controls. This result mirrors a previous study which found a similar relationship between higher frequencies of A-allele carriers and higher concentration of serum CRP levels [14]. Our data is in agreement with a recent study which focused on deep infections, where CRP-286 $(C>T>A)$ polymorphism is found to be significantly associated with maximal CRP levels during the first week of infection [46]. Interestingly, this same triallelic CRP$286(C>T>A)$ polymorphism, which we found to be associated with maximal CRP levels in $S$. aureus bacteraemia, has been related to high basal CRP levels as well [14,46-49]. The triallelic SNP association with CRP level strongly supports recent work described above and represents a reproducible association between genetic variation and this biomarker of high interest. It is known that CRP does not cross the placenta [50]. It is therefore possible to, all the measured levels of CRP are produced by the neonates themselves. Accordingly, previous studies confirm that serum concentrations of CRP and its production in the mother, fetus/newborn are independent of one another; however, the same stimulus may be operating concurrently in each [51]. The major obstetric condition in which determination of maternal serum CRP concentrations might be clinically useful is chorioamnionitis [52].

In this study, we investigated IgG/IgG subclasses as one of the factors of complement activation. The current data showed that the specific antibody levels of IgG, IgG1,
IgG2, and IgG3 were statistically significantly higher in the suspected neonates compared with the EOS group. Much of the knowledge of effector functions of IgG subclasses has been obtained from previous studies with aggregated myeloma proteins, showing that IgG1 binds the complement effectively than IgG2 [53-55]. A recent study in autoimmune disease suggests that the elevated levels of immune complexes (ICs) are associated with increased levels of IgG1 and decreased levels of C3 and C4 in cases of autoimmune pancreatitis, since IgG1 is a molecule capable of activation of the classical pathway [56]. A previous study suggests that the high levels of specific IgG3 antibodies are able to induce a high level of complement activation, and can probably induce local immune complex formation [57]. Given this, it is probable that in our study, the activation of complement via the classical pathway in the sepsis patients might be caused by IGs including the IgG subclasses except for IgG4. However, further studies are needed to investigate the levels of $\mathrm{C} 3$ and $\mathrm{C} 4$ in patients with $S$. aureus infection.

This study demonstrates higher levels of specific IgG2 than IgG3 and IgG1 in suspected newborns compared to EOS groups. The four human IgG subclasses are known to differ in their ability to activate complement $[58,59]$. Specifically, IgG1 and IgG3 antibodies efficiently activate the complement system, whereas IgG2 antibodies are effective mainly at high epitope density, and IgG4 antibodies are ineffective complement activators $[59,60]$.

In general, the high levels of IgG and IgG subclasses can indicate that the mother of the neonate had a previous infection with $S$. aureus during pregnancy. This may subsequently increase the levels of specific IgG antibodies in the newborn, given that IgG is the only antibody that can cross the placenta. Recent studies mentioned that the antibody transfer from mother to baby is an active process that starts early around the gestational age of 16 weeks, but an abundance of IgG is acquired later, during the last 4 weeks of full-term pregnancy $[61,62]$. The transportation of IgG is likely to depend on placental receptors for the Fc part of the antibody (IgG Fc receptor $[\mathrm{Fc} \gamma \mathrm{R}]$ ). Fc $\gamma R$ I and III have a preference for IgG1 and IgG3 and low affinity for IgG2 [63]. However, FcyRIIa has a high affinity to bind IgG2 [64]. This has potential impact on the transfer of antibodies directed to different antigens, because polysaccharides are likely to elicit more IgG2 antibodies [65,66], whereas IgG1 and IgG3 subclasses are directed primarily to proteins $[67,68]$. Factors such as gestational age of the infant at birth, placental abnormalities, and the concentration of specific IgG subclasses in the mother also influence the concentrations in the newborn $[68,69]$. In addition, the impact of different types of $\mathrm{Fc} \gamma \mathrm{R}$ polymorphism on IgG subclasses and susceptibility to sepsis infection in the newborn is important to investigate. 
CRP activates the classical pathway of complement, which is one of its main mechanisms in providing host defence [70]. It has recently been recognised that CRP interacts with the cells of the immune system by binding to Fc $\gamma$ RIIa [19,71]. It may thus bridge the gap between innate and adaptive immunity and provide an early, effective antibacterial response. Furthermore, as it protects against the damaging inflammatory response to lipopolysaccharide and cytokines, it may prevent the lethal side-effects of bacterial products [72]. The recent identification of the interaction of CRP with Fc $\gamma R$ will lead to an enhanced understanding of CRP and its role in both the innate and acquired immune systems [19,71].

This study suggested that higher levels of CRP were negatively associated with levels of IgG2. CRP and IgG share a sequence homology that is important for Fc $\gamma$ RIIa binding [19]. The binding of CRP may compete and interfere with the binding of protective specific IgG antibodies [19]. This finding may explain the important role that high levels of IgG2 can play in reducing the risk of EOS infection in the neonates. The observation in this study provides additional evidence that IgG2 is a good activator of the classical complement pathway. When put together, it is thought that CRP and IgG have several functions including opsonisation [73-75], complement activation by binding $\mathrm{C} 1 \mathrm{q}[76,77]$, and binding to $\mathrm{Fc} \gamma \mathrm{R}[78,79]$.

\section{Conclusions}

Taken together, the CRP-286 (C>T>A) genotype polymorphism and specific IgG antibody subclass levels against neonates infected with $S$. aureus, may contribute to a reduced risk of EOS infection in neonates living in Saudi Arabia. Furthermore, babies carrying the A-allele were associated with high levels of circulating CRP. The higher IgG2 antibody levels associated with lower levels of circulating CRP seen in the study population may be due to the competition between CRP and IgG2 to binding FcyRIIa. Expectedly, the results of this study suggest that the magnitude and the quality of anti-sepsis antibodies (humoral response) are not the only key elements for relative reduction in sepsis infection outcomes. Rather, the results suggest that CRP acting non-specifically, may contribute to the bacterial infection clearance. However, further studies are needed to elucidate whether the FcyRIIa-R/H131 polymorphism is a contributing factor to the differential susceptibility to sepsis infection.

\section{Abbreviations}

CRP: C- reactive protein; EOS: Early onset sepsis; IgG: Immunoglobulin gamma; S. aureus: Staphylococcus aureus.

\section{Competing interests}

The authors declare that they have no competing interests.

\section{Authors' contributions}

AA and ALA designed the study and carried out the sampling; AN and GA performed the ELISA; AN performed the genotyping of CRP polymorphism and participated in the statistical analysis. Both AN and GA drafted the manuscript. AN, AA and GA set up the framework, financed and revised the manuscript. All authors participated in the study design, manuscript preparation, read and approved the final version of the manuscript.

\section{Acknowledgements}

We are grateful to the donors, their families, and the staff at KASH for their participation, sustained cooperation, and generous hospitality during the duration of the fieldwork. We are also grateful to the co-operation of the Al-Neelain Medical Research Centre, Faculty of Medicine, Al-Neelain University, Sudan. We are grateful to Dr. Anhar Yassin for her contribution in improving the science and the language of the manuscript. This work was supported by grants from the Taif University, Ministry of Higher Education, KSA (Grant number: 1-433-1777).

\section{Author details}

${ }^{1}$ Department of Microbiology, College of Medicine, Taif University, Taif, Saudi Arabia. ${ }^{2}$ Department of Basic Medical Sciences, College of Medicine, King Saud bin Abdulaziz University for Health Sciences, Riyadh, Saudi Arabia. ${ }^{3}$ Department of Microbiology, Faculty of Science and Technology, Al-Neelain University, Khartoum, Sudan. ${ }^{4}$ Department of Zoology, Faculty of Science, Beni-Suef University, Beni-Suef, Egypt. ${ }^{5}$ Department of Pediatrics, College of Medicine, Taif University, Taif, Saudi Arabia. 'Department of Neonatology, King Abdel Aziz Specialist Hospital (KAASH), Taif, Saudi Arabia.

Received: 26 April 2013 Accepted: 12 August 2013

Published: 13 August 2013

\section{References}

1. Nelson C: Early recognition and treatment of staphylococcal and streptococcal toxic shock. J Pediatr Adolesc Gynecol 2004, 17:289-292.

2. Stoll BJ, Hansen N: Infections in VLBW infants: studies from the NICHD neonatal research network. Semin Perinatol 2003, 27:293-301.

3. Stoll BJ, Hansen NI, Higgins RD, Fanaroff AA, Duara S, Goldberg R, Laptook A, Walsh M, Oh W, Hale E: Very low birth weight preterm infants with early onset neonatal sepsis: the predominance of gram-negative infections continues in the national institute of child health and human development neonatal research network, 2002-2003. Pediatr Infect Dis J 2005, 24:635-639.

4. McCracken GH Jr: Group B streptococci: the new challenge in neonatal infections. J Pediatr 1973, 82:703-706.

5. Puopolo KM, Madoff LC, Eichenwald EC: Early-onset group B streptococcal disease in the era of maternal screening. Pediatrics 2005, 115:1240-1246.

6. Sheldon TA, Simpson J: Appraisal of a new scheme for prenatal screening for Down's syndrome. Bmj 1991, 302:1133-1136.

7. Jurges ES, Henderson DC: Inflammatory and immunological markers in preterm infants: correlation with disease. Clin Exp Immunol 1996, 105:551-555.

8. Shine B, Gould J, Campbell C, Hindocha P, Wilmot RP, Wood CB: Serum C-reactive protein in normal and infected neonates. Clin Chim Acta 1985, 148:97-103.

9. Peltola $H$, Jaakkola M: Serious bacterial infections. C-reactive protein as a serial index of severity. Clin Pediatr (Phila) 1988, 27:532-537.

10. Peltola $\mathrm{H}$, Jaakkola $\mathrm{M}$ : C-reactive protein in early detection of bacteremic versus viral infections in immunocompetent and compromised children. J Pediatr 1988, 113:641-646.

11. Ohlsson A, Wang E: An analysis of antenatal tests to detect infection in preterm premature rupture of the membranes. Am J Obstet Gynecol 1990, 162:809-818.

12. Pourcyrous M, Bada HS, Korones SB, Barrett FF, Jennings W, Lockey T: Acute phase reactants in neonatal bacterial infection. J Perinatol 1991, 11:319-325.

13. MacGregor AJ, Gallimore JR, Spector TD, Pepys MB: Genetic effects on baseline values of C-reactive protein and serum amyloid a protein: a comparison of monozygotic and dizygotic twins. Clin Chem 2004, 50:130-134.

14. Kovacs A, Green F, Hansson LO, Lundman P, Samnegard A, Boquist S, Ericsson CG, Watkins $\mathrm{H}$, Hamsten A, Tornvall P: A novel common single nucleotide polymorphism in the promoter region of the C-reactive protein gene associated with the plasma concentration of C-reactive protein. Atherosclerosis 2005, 178:193-198. 
15. Carlson CS, Aldred SF, Lee PK, Tracy RP, Schwartz SM, Rieder M, Liu K, Williams OD, Iribarren C, Lewis EC, et al: Polymorphisms within the $\mathrm{C}$-reactive protein (CRP) promoter region are associated with plasma CRP levels. Am J Hum Genet 2005, 77:64-77.

16. Pandey JP: Immunoglobulin GM and KM allotypes and vaccine immunity. Vaccine 2000, 19:613-617.

17. Troye-Blomberg M, Worku S, Tangteerawatana P, Jamshaid R, Soderstrom K, Elghazali G, Moretta L, Hammarstrom M, Mincheva-Nilsson $L$ : Human gamma delta $T$ cells that inhibit the in vitro growth of the asexual blood stages of the Plasmodium falciparum parasite express cytolytic and proinflammatory molecules. Scand J Immunol 1999, 50:642-650.

18. Jefferis R, Kumararatne DS: Selective IgG subclass deficiency: quantification and clinical relevance. Clin Exp Immunol 1990, 81:357-367.

19. Bang R, Marnell L, Mold C, Stein MP, Clos KT, Chivington-Buck C, Clos TW: Analysis of binding sites in human C-reactive protein for Fc\{gamma\}RI, Fc\{gamma\}RIIA, and C1q by site-directed mutagenesis. J Biol Chem 2005, 280:25095-25102.

20. Stein MP, Edberg JC, Kimberly RP, Mangan EK, Bharadwaj D, Mold C, Clos TWD: C-reactive protein binding to FcgammaRlla on human monocytes and neutrophils is allele-specific. J Clin Invest 2000, 105:369-376.

21. Zaidi AK, Thaver D, Ali SA, Khan TA: Pathogens associated with sepsis in newborns and young infants in developing countries. Pediatr Infect Dis $J$ 2009, 28:S10-S18.

22. Shakil S, Khan R, Zarrilli R, Khan AU: Aminoglycosides versus bacteria-a description of the action, resistance mechanism, and nosocomial battleground. J Biomed Sci 2008, 15:5-14.

23. Stoll BJ, Hansen NI, Sanchez PJ, Faix RG, Poindexter BB, Van Meurs KP, Bizzarro MJ, Goldberg RN, Frantz ID III, Hale EC, et al: Early onset neonatal sepsis: the burden of group B Streptococcal and E. coli disease continues. Pediatrics 2011, 127:817-826.

24. Fitness J, Dixit N, Webster D, Torresani T, Pergolizzi R, Speiser PW, Day DJ: Genotyping of CYP21, linked chromosome $6 p$ markers, and a sex-specific gene in neonatal screening for congenital adrenal hyperplasia. J Clin Endocrinol Metab 1999, 84:960-966.

25. Martinez-Picado J, Savara AV, Sutton L, D'Aquila RT: Replicative fitness of protease inhibitor-resistant mutants of human immunodeficiency virus type 1. J Virol 1999, 73:3744-3752.

26. Giha HA, ElGhazali G, Nasr A, Iriemenam NC, Berzins K, Troye-Blomberg M, Theander TG, Arnot D: Clustering of malaria treatment failure (TF) in Daraweesh: hints for host genetic susceptibility to TF with emphasis on immune-modulating SNPs. Infect Genet Evol 2010, 10:481-486.

27. Giha HA, Nasr A, Ekstrom M, Israelsson E, Arambepola G, Arnot D, Theander TG, Troye-Blomberg M, Berzins K, Tornvall $P$, et al: Association of a single nucleotide polymorphism in the C-reactive protein gene $(-286)$ with susceptibility to Plasmodium falciparum malaria. Mol Med 2010, 16:27-33.

28. Israelsson E, Ekstrom M, Nasr A, Dolo A, Kearsley S, Arambepola G, Homann MV, Maiga B, Doumbo OK, Elghazali G, et al: Marked differences in CRP genotype frequencies between the Fulani and sympatric ethnic groups in Africa. Malar J 2009, 8:136.

29. Perlmann H, Perlmann P, Berzins K, Wahlin B, Troye-Blomberg M, Hagstedt M, Andersson I, Hogh B, Petersen E, Bjorkman A: Dissection of the human antibody response to the malaria antigen Pf155/RESA into epitope specific components. Immunol Rev 1989, 112:115-132.

30. Ruths S, Driedijk PC, Weening RS, Out TA: ELISA procedures for the measurement of IgG subclass antibodies to bacterial antigens. J Immunol Methods 1991, 140:67-78.

31. Belady PH, Farkouh LJ, Gibbs RS: Intra-amniotic infection and premature rupture of the membranes. Clin Perinatol 1997, 24:43-57.

32. Kaftan H, Kinney JS: Early onset neonatal bacterial infections. Semin Perinatol 1998, 22:15-24.

33. Denbow M, Fogliani R, Kyle P, Letsky E, Nicolini U, Fisk N: Haematological indices at fetal blood sampling in monochorionic pregnancies complicated by feto-fetal transfusion syndrome. Prenat Diagn 1998, 18:941-946.

34. Goldstein B, Giroir B, Randolph A: International pediatric sepsis consensus conference: definitions for sepsis and organ dysfunction in pediatrics. Pediatr Crit Care Med 2005, 6:2-8.

35. Resch B, Gusenleitner W, Muller W: Procalcitonin, interleukin-6, C-reactive protein and leukocyte counts in infants with bronchiolitis. Pediatr Infect Dis J 2003, 22:475-476.
36. Resch B, Gusenleitner W, Muller WD: Procalcitonin and interleukin-6 in the diagnosis of early-onset sepsis of the neonate. Acta Paediatr 2003, 92:243-245.

37. ACOEPCPSOP Fevere: Clinical policy for children younger than three years presenting to the emergency department with fever. Ann Emerg Med 2003, 42:530-545.

38. Maayan-Metzger A, Mazkereth R, Kuint J: Fever in healthy asymptomatic newborns during the first days of life. Arch Dis Child Fetal Neonatal Ed 2003, 88:F312-F314.

39. Voora S, Srinivasan G, Lilien LD, Yeh TF, Pildes RS: Fever in full-term newborns in the first four days of life. Pediatrics 1982, 69:40-44.

40. Cheng TL, Partridge JC: Effect of bundling and high environmental temperature on neonatal body temperature. Pediatrics 1993, 92:238-240.

41. Van Sleuwen BE, Engelberts AC, Boere-Boonekamp MM, Kuis W, Schulpen TW, L'Hoir MP: Swaddling: a systematic review. Pediatrics 2007, 120:e1097-e1106.

42. Berger C, Uehlinger J, Ghelfi D, Blau N, Fanconi S: Comparison of C-reactive protein and white blood cell count with differential in neonates at risk for septicaemia. Eur J Pediatr 1995, 154:138-144.

43. Enguix A, Rey C, Concha A, Medina A, Coto D, Dieguez MA: Comparison of procalcitonin with $C$-reactive protein and serum amyloid for the early diagnosis of bacterial sepsis in critically ill neonates and children. Intensive Care Med 2001, 27:211-215.

44. Simon L, Gauvin F, Amre DK, Saint-Louis P, Lacroix J: Serum procalcitonin and C-reactive protein levels as markers of bacterial infection: a systematic review and meta-analysis. Clin Infect Dis 2004, 39:206-217.

45. Noor MK, Shahidullah M, Mutanabbi M, Barua C, Mannan MA, Afroza S: Comparison between CRP and IL- 6 as early markers of neonatal sepsis. Mymensingh Med J 2008, 17:S72-S76.

46. Molkanen T, Rostila A, Ruotsalainen E, Alanne M, Perola M, Jarvinen A: Genetic polymorphism of the C-reactive protein (CRP) gene and a deep infection focus determine maximal serum CRP level in Staphylococcus aureus bacteremia. Eur J Clin Microbiol Infect Dis 2010, 29:1131-1137.

47. Kathiresan S, Larson MG, Vasan RS, Guo CY, Gona P, Keaney JF Jr, Wilson PW, Newton-Cheh C, Musone SL, Camargo AL, et al: Contribution of clinical correlates and $13 \mathrm{C}$-reactive protein gene polymorphisms to interindividual variability in serum C-reactive protein level. Circulation 2006, 113:1415-1423.

48. Suk Danik J, Chasman DI, Cannon CP, Miller DT, Zee RY, Kozlowski P, Kwiatkowski DJ, Ridker PM: Influence of genetic variation in the C-reactive protein gene on the inflammatory response during and after acute coronary ischemia. Ann Hum Genet 2006, 70:705-716.

49. Szalai AJ, Wu J, Lange EM, McCrory MA, Langefeld CD, Williams A, Zakharkin SO, George V, Allison DB, Cooper GS, et al: Single-nucleotide polymorphisms in the C-reactive protein (CRP) gene promoter that affect transcription factor binding, alter transcriptional activity, and associate with differences in baseline serum CRP level. J Mol Med (Berl) 2005, 83:440-447.

50. Jaye $\mathrm{DL}$, Waites KB: Clinical applications of $\mathrm{C}$-reactive protein in pediatrics. Pediatr Infect Dis J 1997, 16:735-746. quiz 746-7.

51. Chiesa C, Signore F, Assumma M, Buffone E, Tramontozzi P, Osborn JF, Pacifico L: Serial measurements of C-reactive protein and interleukin-6 in the immediate postnatal period: reference intervals and analysis of maternal and perinatal confounders. Clin Chem 2001, 47:1016-1022.

52. Chaisilwattana P, Monif GR: Potential use of C-reactive protein determinations in obstetrics and gynecology. Obstet Gynecol Surv 1989, 44:355-360

53. Bredius RG, Driedijk PC, Schouten MF, Weening RS, Out TA: Complement activation by polyclonal immunoglobulin $\mathrm{G} 1$ and $\mathrm{G} 2$ antibodies against Staphylococcus aureus, Haemophilus influenzae type $b$, and tetanus toxoid. Infect Immun 1992, 60:4838-4847.

54. Ishizaka T, Ishizaka K, Salmon S, Fudenberg H: Biologic activities of aggregated gamma-globulin. 8. Aggregated immunoglobulins of different classes. J Immunol 1967, 99:82-91.

55. Schumaker VN, Calcott MA, Spiegelberg HL, Muller-Eberhard HJ: Ultracentifuge studies of the binding of IgG of different subclasses to the Clq subunit of the first component of complement. Biochemistry 1976, 15:5175-5181.

56. Muraki T, Hamano H, Ochi Y, Komatsu K, Komiyama Y, Arakura N, Yoshizawa K, Ota M, Kawa S, Kiyosawa K: Autoimmune pancreatitis and complement activation system. Pancreas 2006, 32:16-21.

57. Pressler T, Jensen ET, Espersen F, Pedersen SS, Hoiby N: High levels of complement-activation capacity in sera from patients with cystic fibrosis correlate with high levels of lgG3 antibodies to Pseudomonas 
aeruginosa antigens and poor lung function. Pediatr Pulmonol 1995, 20:71-77.

58. Burton DR, Gregory L, Jefferis R: Aspects of the molecular structure of IgG subclasses. Monogr Allergy 1986, 19:7-35.

59. Michaelsen TE, Garred P, Aase A: Human lgG subclass pattern of inducing complement-mediated cytolysis depends on antigen concentration and to a lesser extent on epitope patchiness, antibody affinity and complement concentration. Eur J Immunol 1991, 21:11-16.

60. Garred P, Michaelsen TE, Aase A: The IgG subclass pattern of complement activation depends on epitope density and antibody and complement concentration. Scand J Immunol 1989, 30:379-382.

61. Shah U, Dickinson BL, Blumberg RS, Simister NE, Lencer WI, Walker WA Distribution of the $\operatorname{lgG}$ Fc receptor, FcRn, in the human fetal intestine. Pediatr Res 2003, 53:295-301.

62. Simister NE: Placental transport of immunoglobulin G. Vaccine 2003, 21:3365-3369.

63. Takizawa T, Anderson CL, Robinson JM: A novel Fc gamma R-defined, IgG-containing organelle in placental endothelium. J Immunol 2005, 175:2331-2339.

64. Nasr A, Iriemenam NC, Giha HA, Balogun HA, Anders RF, Troye-Blomberg M, EIGhazali G, Berzins K: FcgammaRlla (CD32) polymorphism and anti-malarial IgG subclass pattern among Fulani and sympatric ethnic groups living in eastern Sudan. Malar J 2009, 8:43.

65. Findlow H, Southern J, Mabey L, Balmer P, Heyderman RS, Auckland C, Morris R, Miller E, Borrow R: Immunoglobulin $G$ subclass response to a meningococcal quadrivalent polysaccharide-diphtheria toxoid conjugate vaccine. Clin Vaccine Immunol 2006, 13:507-510.

66. Soininen A, Seppala I, Nieminen T, Eskola J, Kayhty H: IgG subclass distribution of antibodies after vaccination of adults with pneumococcal conjugate vaccines. Vaccine 1999, 17:1889-1897.

67. Malek A, Sager R, Schneider H: Maternal-fetal transport of immunoglobulin $\mathrm{G}$ and its subclasses during the third trimester of human pregnancy. Am J Reprod Immunol 1994, 32:8-14.

68. Nahm MH, Glezen P, Englund J: The influence of maternal immunization on light chain response to Haemophilus influenzae type $b$ vaccine. Vaccine 2003, 21:3393-3397.

69. Healy CM, Baker CJ: Prospects for prevention of childhood infections by maternal immunization. Curr Opin Infect Dis 2006, 19:271-276.

70. Suresh MV, Singh SK, Ferguson DA Jr, Agrawal A: Role of the property of C-reactive protein to activate the classical pathway of complement in protecting mice from pneumococcal infection. J Immunol 2006, 176:4369-4374.

71. Ferri C, Croce G, Cofini V, De Berardinis G, Grassi D, Casale R, Properzi G, Desideri G: C-reactive protein: interaction with the vascular endothelium and possible role in human atherosclerosis. Curr Pharm Des 2007, 13:1631-1645.

72. Li JJ, Chen XJ: Simvastatin inhibits interleukin-6 release in human monocytes stimulated by C-reactive protein and lipopolysaccharide. Coron Artery Dis 2003, 14:329-334

73. Kilpatrick JM, Volanakis JE: Opsonic properties of C-reactive protein Stimulation by phorbol myristate acetate enables human neutrophils to phagocytize C-reactive protein-coated cells. J Immunol 1985, 134:3364-3370.

74. Kindmark CO: Stimulating effect of C-reactive protein on phagocytosis of various species of pathogenic bacteria. Clin Exp Immunol 1971, 8:941-948.

75. Mortensen RF, Osmand AP, Lint TF, Gewurz H: Interaction of C-reactive protein with lymphocytes and monocytes: complement-dependent adherence and phagocytosis. J Immunol 1976, 117:774-781.

76. Kaplan MH, Volanakis JE: Interaction of C-reactive protein complexes with the complement system. I. Consumption of human complement associated with the reaction of C-reactive protein with pneumococca C-polysaccharide and with the choline phosphatides, lecithin and sphingomyelin. J Immunol 1974, 112:2135-2147.

77. Volanakis JE, Kaplan MH: Interaction of C-reactive protein complexes with the complement system. II. Consumption of guinea pig complement by CRP complexes: requirement for human C1q. J Immunol 1974, 113:9-17.
78. Crowell RE, Du Clos TW, Montoya G, Heaphy E, Mold C: C-reactive protein receptors on the human monocytic cell line U-937. Evidence for additional binding to Fc gamma RI. J Immunol 1991, 147:3445-3451.

79. Marnell LL, Mold C, Volzer MA, Burlingame RW, Clos TWD: C-reactive protein binds to Fc gamma RI in transfected COS cells. J Immunol 1995, 155:2185-2193.

doi:10.1186/1471-2172-14-38

Cite this article as: Nasr et al:: Neonatal infections in Saudi Arabia: association with C-reactive protein, $C R P-286(C>T>A)$ gene polymorphism and IgG antibodies. BMC Immunology 2013 14:38.

\section{Submit your next manuscript to BioMed Central and take full advantage of:}

- Convenient online submission

- Thorough peer review

- No space constraints or color figure charges

- Immediate publication on acceptance

- Inclusion in PubMed, CAS, Scopus and Google Scholar

- Research which is freely available for redistribution

Submit your manuscript at www.biomedcentral.com/submit
C) BioMed Central 